\title{
Correction
}

\section{Correction: Mark et al., Spinocerebellar Ataxia Type 6 Protein Aggregates Cause Deficits in Motor Learning and Cerebellar Plasticity}

In the article "Spinocerebellar Ataxia Type 6 Protein Aggregates Cause Deficits in Motor Learning and Cerebellar Plasticity" by Melanie D. Mark, Martin Krause, Henk-Jan Boele, Wolfgang Kruse, Stefan Pollok, Thomas Kuner, Deniz Dalkara, Sebastiaan Koekkoek, Chris I. De Zeeuw, and Stefan Herlitze, which appeared on pages 8882-8895 of the June 10, 2015 issue, the authors regret an error in Figure $7 C$, right panel. The color of the data points in the line graph for the fl-CT-longQ27 and the CT-longQ $27^{\mathrm{PC}}$ were accidentally switched. The correct Figure 7 is shown on the next page. 
A

Experimental Procedure

\begin{tabular}{|l|l|l|l|l|l|l|l|l|l|l|l|}
\hline 1 & 2 & 3 & 4 & 5 & 6 & 7 & 8 & 9 & 10 & 11 & 12 \\
\hline
\end{tabular}

\begin{tabular}{|l|l|l|}
\hline Habituation & Conditioning & Extinction \\
\hline
\end{tabular}

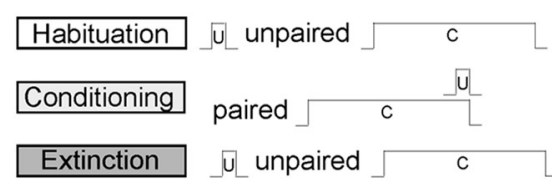

US = corneal air puff $(30 \mathrm{~ms})$

$\mathrm{CS}=$ auditory tone $(380 \mathrm{~ms})$

B
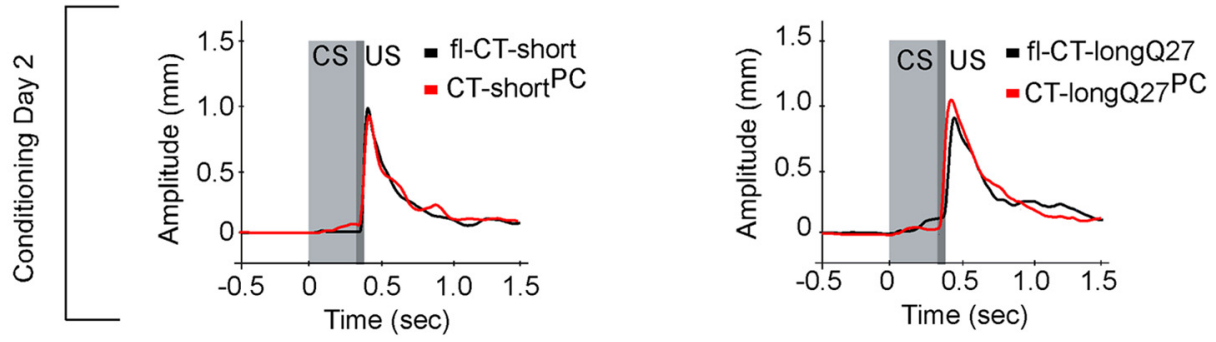

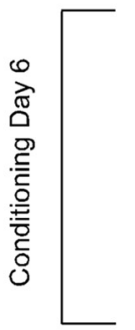
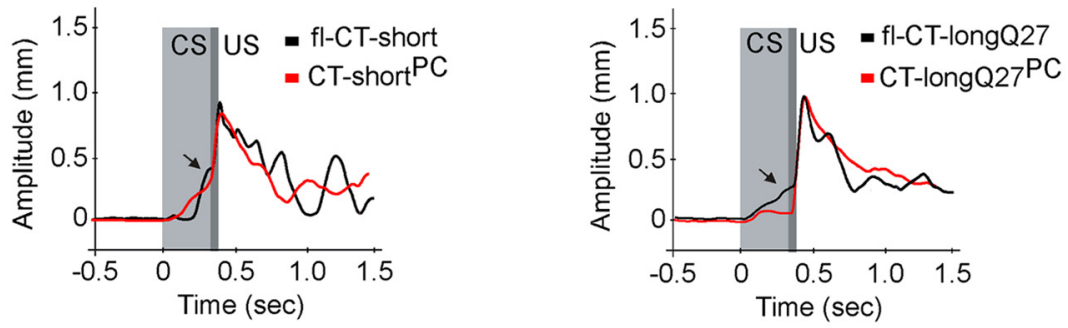

C
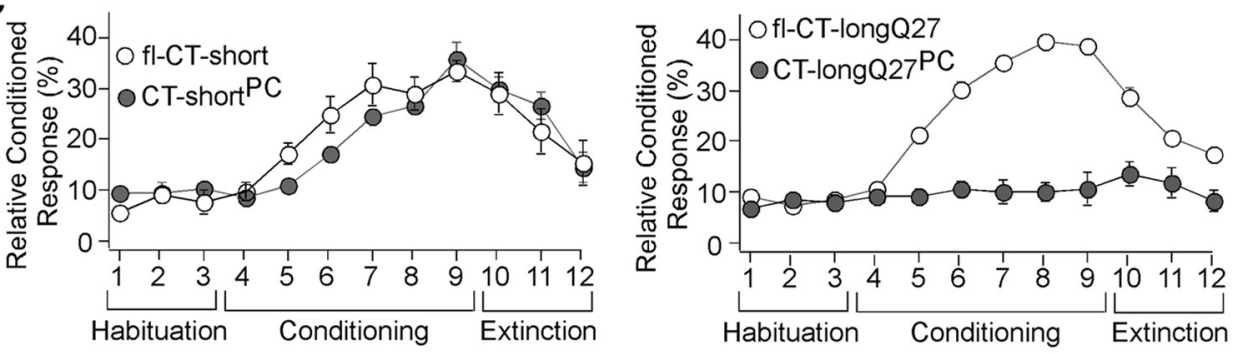

D
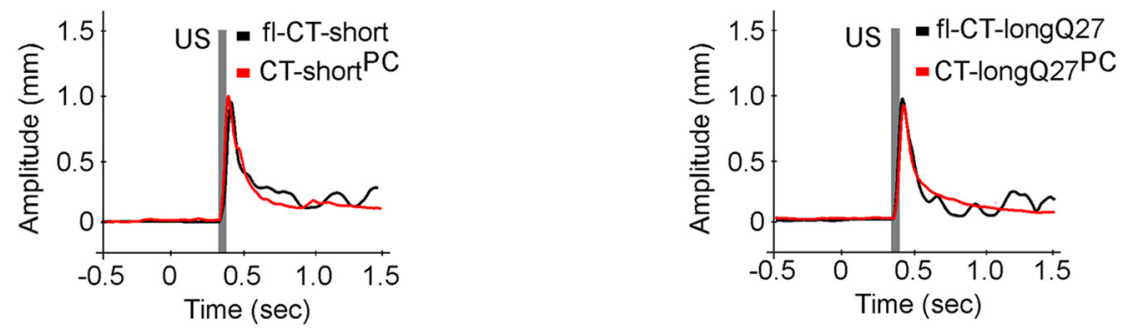

E
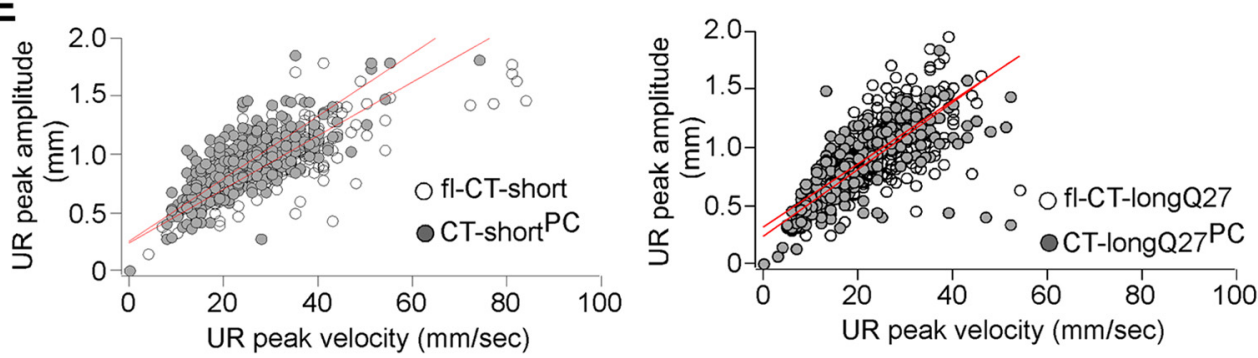

Figure 7. 